\title{
Knowledge-based startups or small companies' mergers \& acquisitions: an antitrust debate? Recent cases from US, EU and Brazil
}

\author{
Camila C. Pires-Alves*, Manuel Gonzalo** and Marcos Puccioni de Oliveira Lyra***
}

\begin{abstract}
The emergence of a new techno-economic paradigm mainly based in the ICT technologies naturally have influenced the ongoing antitrust debate. This paper is devoted to answer two questions. First, how the antitrust authorities should consider knowledge-based startups or small companies acquisitions. Second, what are the current institutional challenges in this topic. Despite this discussion is not much explored in the literature, we looked at the antitrust theoretical debate and examined the recent merger cases in the United States and in the European Union in order to extract some insights about these questions. Also, we briefly explored some selected Brazilian recent cases to draw some policy and academic further agenda in this country. We can sustain that market shares are not an accurate proxy for market power considering the ability of succeed in innovation strategies; they can be highly volatile or cannot appropriately show the firm's potential in the competition for innovation. We see that there are important contributions to present general principles concerning the incentives to innovate post-merger. Nevertheless, they were designed to accomplish all kind of merger effects in innovation. For the startups or small firms case, we raised some issues to be addressed: the small or even non-existent market share and the importance of identifying the buyer and their changes in incentives to maintain the innovation path are some specificity that turns the analyses even more complex. There are relevant gap for the antitrust authorities, as the submission threshold are mainly based on companies revenues. The introduction of additional thresholds for the value of transaction may be a starting point.
\end{abstract}

Keywords: antitrust / competition policy/startups / small enterprises / innovation / US / EU / Brazil

\section{RESUMO}

A emergência do novo paradigma tecno-econômico baseado nas TICs tem influenciado o debate antitruste. Este trabalho busca responder duas perguntas. Primeiro, como as autoridades antitruste deveriam considerar as aquisições de startups ou pequenas empresas de base tecnológica. Segundo, quais são os desafios institucionais que se apresentam nesta área. Apesar da escassez de literatura específica, apresenta-se o debate conceitual e teórico existente e examinam-se casos recentes nos Estados Unidos e na União Europeia procurando encontrar questões relevantes para responder ao objetivo proposto. Também se apresentam alguns casos recentes do Brasil para trazer recomendações gerais e guiar desdobramentos para pesquisa futura. Podemos sustentar que participações de mercado não são uma boa proxy de poder de mercado no que refere ao sucesso da estratégia de inovação das firmas, porque pode ser volátil no curto-prazo ou não demonstrar o potencial da empresa na concorrência por inovação. Vimos que há importantes contribuições no sentido de sintetizar em princípios gerais e comportamentos possíveis quanto aos incentivos a inovar pós-fusão. Entretanto, foram desenhados a partir de qualquer efeito em inovação, e ainda assim não possuem sistematização e procedimentos bem definidos na experiência internacional. No caso das empresas pequenas ou startups, levantamos algumas questões a serem abordadas: o market share reduzido ou inexistente, a importância de identificar o comprador e suas mudanças nos incentivos para manter a inovação são algumas especificidades que tornam as análises ainda mais complexas. Há, ainda, importante defasagem das autoridades no acompanhamento desses casos uma vez que os critérios de notificação estão amparados em faturamento das empresas ou grupos. Finalmente, a introdução de critérios que consideram o valor da transação pode ser um bom ponto de partida.

Palavras chave: antitruste / defesa da concorrência / startups / pequenas empresas /inovação/ US / UE / Brasil JEL L40 - AREA ABEIN 6.4

\footnotetext{
* Associate Professor, Institute of Economics of the Federal University of Rio de Janeiro, Coordinator and member of Gdec (Research Group in Law, Economics, and Competition), Institute of Economics of the Federal University of Rio de Janeiro (IE/UFRJ), member of GIC (research group of industry and competitiveness). E-mail: camila.alves@ie.ufrj.br ** PhD Student, Institute of Economics of the Federal University of Rio de Janeiro (IE/UFRJ), research assistant at RedeSist (IE-UFRJ) and researcher-professor at ProDem (IDEI/UNGS) E-mail: gonzalo.manolo@gmail.com *** Researcher at Gdec (Research Group in Law, Economics, and Competition) and $\mathrm{MsC}$, Institute of Economics of the Federal University of Rio de Janeiro (IE/UFRJ). Email: marcosplyra@gmail.com
} 


\section{Introduction}

The new technological paradigm and the recent changes in the functioning of markets and economies show us the great importance of well succeeded innovation. The expansion of capitalism through long technological waves has been an area crafted by highly recognized economists, such as Schumpeter. More contemporarily, capitalism progress is understood from a technological or techno-economic paradigms approach. Roughly speaking, system progress would be pulled by a succession of technological revolutions, which introduces a new 'key' transversal technology or infrastructure that modifies the relative costs in most of the sectors of the economy and results in a jump in overall productivity (Dosi, 1982, 1984; Perez, 2001, 2002). In this context, in parallel to the emergence of a new techno-economic paradigm, several entrepreneurial opportunities appear. With the adequate funding, capabilities and institutional support, the new businesses associated to the new techno-economic paradigm may be a 'window of opportunity' to the so called 'catching up' process (Perez and Soete, 1988; Perez, 2002).

At national level, many countries have implemented different programs and developed a great number of institutions dedicated to promoting the emergence and consolidation of well succeeded innovation strategies. Some of these include incentives and promotion of knowledge-based startups and small companies. In fact, over the last two decades, it is a recurrent part of public policy to create institutions and programs that support the conception and development of firms with high-growth potential, particularly those based on knowledge and innovation (Audretsch et al., 2002; Lundström and Stevenson, 2005). Business incubators and accelerators, university programs, the promotion of academic spin-offs, and the development of venture capital supply are the main instruments that have been used to this end (Gilbert et al, 2004; European Commission, 2004; Zavatta, 2008, Kantis et al., 2004). The hypothesis that underpins these policies and institutional efforts is that these firms could become a driving force towards economic renewal through: i) the generation and diffusion of innovations; ii) the gathering of know-how and existing knowledge; iii) the generation of new highly qualified jobs, iv) the appearance of new sectors and activities; v) the change in each economy's specialization pattern; and vi) the regional development (Audretsch and Keilbach, 2007; Audretsch and Thurik, 2000; Autio, 1997; Fontes and Coombs, 2001; Danson, 1996; Mason and Harrison, 2006).

In the last decade, Latin American countries have also supported several projects and institutions dedicated to promote the emergence and consolidation of knowledge-based entrepreneurial ecosystems (Kantis et al, 2013, 2004). This is particularly the case of the main sectors of the new techno-economic paradigm such as information and communication technologies (ICT), biotechnology and audiovisual (Ceria and Palotti, 2010, Uriona Maldonado et al, 2013). However, in an increasingly global competitive environment, many startups that emerged were acquired by global and large companies, particularly those that have shown an innovative performance and superlative growth rates (Gonzalo, 2015; Gonzalo et al, 2013; $2011)^{2}$. Although in some cases, these purchases have resulted in an expansion of the activities of these firms, maintaining the R\&D activities, in many other cases, these takeovers ${ }^{3}$ implied a termination of local businesses, which was a current or potential competitor of the acquirer firms or a source of innovation. This process of takeover could be interpreted as the 'Latin American paradox of entrepreneurial success'. In Wasserman (2003), the paradox of entrepreneurial success referred to the replacement of the successful entrepreneurs by the CEOs elected by the ventured capital funds. In Latin America, the process is similar, but additionally, it is not only the entrepreneur that is replaced, but also the R\&D team or even the whole firm may be closed.

\footnotetext{
${ }^{2}$ According to CrunchBase base, more than 20 young knowledge-based firms from the Argentina, Bolivia, Brazil, Chile, Paraguay and Uruguay were acquired in 2016 (CrunchBase, 2016).

${ }^{3}$ In this paper, we will use takeovers, acquisitions and mergers as synonyms.
} 
Although one can argue that most of the entrepreneurs and startup economic logic is to be sold, in terms of public policy perspective, it is important to wonder what would be the result to technological diversity, innovation or welfare ${ }^{4}$. The main objective of this paper is to reflect on the antitrust ${ }^{5}$ implications of the startups and small firms takeovers. First, it is considered whether the acquisition of a startup or small but innovative company may have an anticompetitive effect, such as preventing entrance, reducing the incentives to innovate or altering the innovative and competitive dynamic. That said, we discuss whether these mergers do not deserve a particular look by competition and innovation policy authorities. In particular, considering the competition policy goal, we ask: is the anticompetitive assumption valid and in which cases? How should the antitrust authorities consider these mergers? What are the main challenges?

As dealing with mergers in innovative markets is already a challenge, the proposed discussion is absent in the current antitrust literature. In fact, although the 'knowledge-based startups acquisitions' is being increasingly discussed in American, European and Asian specialized IT and business blogs and magazines, there is not much articulated academic research discussing this matter, specially combining innovation and competition policy motivations. Between the works that indirectly debate this issue, Mandel and Carew (2011) analyze it from an ecosystem's perspective, sustaining that startups acquisitions by an incumbent firm mainly improve the innovation dynamic of the ecosystem as a hole. Audretsch et al (2001) and Audretsch (2013) also introduce some insights about the relationship between entrepreneurship and competition policy, although in a very general sense and without expanding in how the antitrust authorities may evaluate these sorts of mergers.

In order to make a contribution in this unexplored field and answer our research questions, in the next section we present a brief outline of the actual antitrust merger review. Discussion about the subject is still embrionary, but some advances in enforcement may be seen, especially in opposition to standard approach. Later, in the third section, the antitrust conceptual debate is further developed to mergers impacts in innovation and we introduce some considerations about the startups and small knowledge-based firms' acquisitions analyses, as a special case. Then, we present and analyze two international cases and their peculiarities: the Google/Waze acquisition and the Facebook/WhatsApp case. These cases were chosen because they fit and illustrate well the arguments presented in the literature review. The first one is an example of a firm with high innovative potential not reflected in its current revenue, influencing the minimum criteria for investigation; the second one is an illustration of an acquisition of a firm that cannot be considered a startup or small company, but reflects the agency's view of the innovative dimension and merger effect in a market that is characterized by short and dynamic cycles of innovation. Finally, we address some recent experiences in Brazil and raise some lessons and challenges to the Brazilian authority. In the conclusion section, we present some suggestions for policy and for future research.

Undoubtedly, it is an initial conceptual and policy oriented effort in a relatively new field. So, despite drawing definitive conclusions, our main objective is to introduce this discussion and present the most relevant topics in perspective. However, we consider that this paper has two main and significant contributions. First, we set up an initial conceptual discussion and analyze a startup or small and highly innovative firm acquisition from a merger antitrust approach, deepening in the innovative implications of the merger. As said, there are no works in Latin America and few works around the world in general that explore

\footnotetext{
${ }^{4}$ Different Latin American economist such as Ferrer (1963), Sunkel (1971), Fajnzylber (1983) and Tavares (1985) have pointed out the implications of the transnational takeovers for the development of local entrepreneurial and technological capabilities. Transnational enterprises, backed by their better financial access and government of origin support, might acquire local firms without dislocating the R\&D activities. More contemporary, Soares et al (2015) and Szapiro et al (2015) sustain that the transnational enterprises presence in Latin American countries has not always been virtuous and in many cases it may 'lock' the development of local technologies, entrepreneurial and collective capabilities. Given that the structural heterogeneity is still a main feature of the Latin American productive structures, the 'foreignization' of the local young firms related to the new technoeconomic paradigm firms gives a new face to a not so new discussion.

${ }^{5}$ In this paper we will consider antitrust and competition policy as synonymous.
} 
this line of analysis. Second, we suggest some initial potential lines of dialogue around the need to coordinate competition and innovation policy, particularly in Brazil.

\section{The current conventional merger approach}

This section will briefly consider the current procedures and the more important merger analysis' characteristics.

After the second world-war, it started the biggest controversy in the history of US antitrust law. As Budzinski (2008) says, the most famous controversy among competition theories is represented by the Harvard-Chicago controversy. Harvard school is mainly based on the structure-conduct-performance paradigm and understands antitrust policy as part of an overall economic policy strategy to achieve certain social objectives. It is, in general terms, a pro-intervention approach. Harvard predominated between the 40s and 60s. According to Motta (2004), this was a period more characterized by a desire to restrict large firms than for a concern with efficiency.

The 70s and 80s were for the Chicago school. The drop of US productivity in the 70s, the critics from Chicago School to Harvard and Reagan's victory in 1981 opened the path to a 'hand off' period, of less intervention by the American authorities (Motta, 2004). Conceptually, this policy shift was also followed by new theoretical developments such as the contestable markets theory. For its part, the Chicago school believes that the free functioning of markets is the best way to achieve social welfare. Thus, efficiency is the only goal of antitrust policy. As pointed Budzinski (2008, p. 300), the static allocative efficiency, not concerning distributive issues, is the basis of the Chicago School:

Efficiency gains are proposed if a change in market performance enhances welfare, which is defined as quantifiable changes in consumers' surplus and producers' surplus (neglecting any type of non-quantifiable effects). In doing so, Chicago economics focus on a total welfare standard, i.e. competition policy should maximize the sum of consumers' and producers' rents. Therefore, the Chicago School does not identify a competition problem if consumers' surplus is converted into producers' surplus as long as the net effect is not negative.

From the mid-90s on, as highlighted Budzinski (2008), based on different applications of industrial organization theories, conceptual contributions to the antitrust area that have been grouped together in what is called the post-Chicago approach. Overall, these approaches share a more critical stance regarding the markets auto-organization capacity to achieve the greatest long-term social welfare when compared to Chicago. Methodologically, there are some post-Chicago contributions such as game theory, theory-based empirical studies, use of econometrics, etc. Conceptually, there are distinct contributions that were neglected by the Chicago school and a dialogue between Chicago and structuralist ideas, such as the theory of strategic barriers to entry and coordinated and unilateral effects in oligopolistic theory, as highlights.

The current conventional approach to antitrust policy is based mainly on a static view of competition, and is designed to pursue the goal of reaching the most efficient allocation. In order to reach the goal of preserving welfare, the antitrust authority uses the Paretian Criteria ${ }^{6}$. The focus is on diminishing the so called "deadweight loss" and, by preventing excessive post-merger concentration, the authority is avoiding a larger deadweight loss or the reduction of consumer welfare, only when it will likely lead to higher prices or other forms of abuse of market power. The analysis occurs following the rule of reason: merger is not prohibited per se, the benefits (efficiencies) and the anticompetitive effects are balanced and it is approved in case of positive net effect. If the net effect is negative, the merger is blocked or allowed with the imposition of restriction to diminish anticompetitive concerns, also known as remedies.

\footnotetext{
${ }^{6}$ If an allocation is efficient in Pareto sense, there is no other allocation that is better for all agents involved. In other words, there is no way to improve someone's situation without making it worse for at least one other agent.
} 
About merger analysis itself, the current procedure can be divided in four main steps: i) market definition; ii) concentration analysis; iii) entry conditions, iv) anticompetitive effects evaluation and v) efficiencies analysis. In most of the cases, the first step consists in defining the relevant market both in its product and geographic dimensions (checking the substitutability degree between products and geographic areas, considering demand side, mainly). The second step is evaluating market shares and concentration indexes, such as the Herfindahl-Hirschman Index $(\mathrm{HHI})^{7}$ to assess the "likelihood of having adverse competitive effects" as defined by the US Horizontal Merger Guidelines, the document that guides merger assessment by the US Agencies. Analyzing entry is also an important step, by considering entry barriers and conditions, and also its likelihood, timeliness and sufficiency.

By checking the likelihood of anticompetitive effects, the authorities will have two main concerns: the unilateral and coordinated effects. The first one happens when it is expected that the merged firm will increases post-merger prices (or reduce innovation, quality, etc.) by its own, while the second one happens through the higher likelihood of coordination between the merged firm and other competitors (coordination may occur explicitly or tacitly).

As a result of Chicago contributions, it is considered that some mergers can actually improve welfare (reduce prices, improve quality, innovation, variety, etc.): the last step is evaluating if there are alleged efficiencies that can be achieved exclusively through the merger. After measuring the effect in pricing of both anticompetitive effects and efficiencies, the antitrust authorities evaluate the net effects of these two opposing forces.

Not all mergers and acquisitions need to be analyzed by the antitrust authorities, as they usually establish a threshold for size of firms and transaction value for merger notification. Indeed, there is a presumption that a merger between small firms will not harm competition. The FTC, for example, follows the so-called Hart-Scott-Rodino (HSR) Act, that establishes threshold values for premerger notification. Currently the transaction value threshold for premerger notification is $\$ 80.8$ million $^{8}$, while sizes of parties vary from $\$ 16.2$ million and $\$ 161.5$ million. Below these values, parties are not obliged to notify the FTC. However, if the transaction value exceeds the amount of US\$323 million, it needs to be independently of the size of the parties. There are two alternative ways that makes a merger gets reviewed by the European Commission: the first is if the combined turnover of the merging companies is over 5 billion euros worldwide and 250 million euros EU- wide; the second is if the combined turnover is over 2.5 billion euros worldwide, there is a combined turnover of at least 100 million euros in at least three Member States; a turnover of 35 million euros for each of at least two of the merging firms in each of the three Member States and a EU-wide turnover of at least two firms of more than 100 million euros EU-wide. ${ }^{9}$

To sum up, this section became an embryonic outline aimed to show that the evolution of antitrust policy and its enforcement is not a static or free of tension area. The political, competitive, technological and external insertion phase have influenced both in the conceptual debate and in the enforcement of the law. Going back to our main subject, innovation is a topic of great importance in the competition process and global economy new scenario. Although it is possible to state that while competition is changing radically with the rise of more dynamic markets such as IT, competition policy is not changing as fast. We introduced the conventional merger approach in this section; the antitrust debate for merger involving innovative industries and its implication are presented in the next one.

\section{Merger analysis with Schumpeterian competition: knowledge-based startups and small companies acquisitions as a special case}

\footnotetext{
${ }^{7} \mathrm{HHI}$ is measured by adding the square of all firms' market share and multiplying it by 10,000 .

${ }^{8}$ https://www.ftc.gov/system/files/documents/federal_register_notices/2017/01/clayton_7a_publishe_1-26-17.pdf

9 http://ec.europa.eu/competition/mergers/procedures_en.html
} 
In this section, we introduce different views related to the introduction of innovation dimension when assessing merger effects in Schumpeterian markets (or knowledge-based as we have named), in order, at the end, to be capable to discuss the knowledge-based startups mergers. In this matter, we first consider the usual critics to the standard approach. Then, we describe the implications to merger analysis and desirable changes, according both to the more radical and soft authors. Three main themes are introduced: the relevant markets concept adequacy; the necessity of considering firm's capabilities to innovate, and the factors that influence the incentives of firms to innovate and how they may change after the merger. About this last concern, we can highlight the contributions that raised the importance of preserving diversity and the incentives principles proposed by Shapiro (2011), both fulfilling the conceptual debate.

Before going further in the debate, we should say that economic theory did not advance in finding a clear causality link between innovation and concentration, and there is no final answer to the Arrow/Schumpeter controversy ${ }^{10}$, even though theoretical and empirical work has been done exhaustively. Knowing so, evaluating market concentration may not give us the right clue about the likelihood of anticompetitive merger effects in innovation. This is particularly true when considering knowledge or technological-based markets: competition occurs at innovation levels or, in other words, there is Schumpeterian competition ${ }^{11}$. So, as there is no final conclusion to the relation between innovation and concentration, no assumptions about the effects of the merger should be made looking solely to changes in concentration when evaluating a case with innovation competition: mergers should be analyzed on a case by case basis.

That being said, there is an ongoing debate on how to incorporate innovation in merger review. There are different approaches. Some authors prefer to follow the conventional step-by-step merger analysis with changes in the steps themselves such as Shapiro (2011), Baker (2008), Katz and Shelanski (2007), while some others prefer a more radical departure from conventional merger analysis, as Sidak and Teece (2009), Jorde and Teece (1990), Kerber (2010), Budzinski (2007) and Farrel (2006).

The first source of general criticism of the traditional approach in merger analysis is that, by following the mainstream theoretical and methodological approach, antitrust policy ends up focusing on price competition instead of innovation competition. As a result, antitrust policy generally gives no proper treatment when evaluating the likelihood of negative effects to variety, quality and innovation in merger control analysis. However, despite the criticism, it is important to mention that there are some recent changes that may be seen in the opposite direction: some specific cases where price was not the most important dimension of competition considered ${ }^{12}$, but changes are far from satisfactory yet.

Other tension may be the reflection of a trade-off between static and dynamic competition, and between short-run and long-run in merger analysis. In other words, the antitrust agency sometimes will have to decide whether to focus on static price effects or on dynamic innovation and price effects. Choosing the first option can be harmful to innovation, as enforcement can be too harsh in a market where innovation may alter future prices. On the other hand, making innovation the priority may include price increases in the shortrun, diminishing consumers' supply. Promoting dynamic competition can interrupt price competition, as Sidak and Teece (2009) explain. It also important to have in mind that choosing to focus in one of these two options does not mean that the agency will completely forget the other one, there are middle grounds, but deciding it will be the authorities' call and the best decision will mostly depend on the case analyses.

\footnotetext{
${ }^{10}$ Kenneth Arrow favor the hypothesis that less concentration is better for innovation, while Joseph Schumpeter supposedly favors the idea that concentrated structures are better for innovation. Aghion et alli (2002) defends a middle-ground answer: some concentration is good up to a certain level, and after that level it starts to be prejudicial to innovation, the so called inverted $U$ relationship. See also Dosi (1984) for a discussion about concentration and innovation.

${ }^{11}$ In general terms, the Schumpeterian competition is the process of competition through innovation in a dynamic environment, the opposite of the orthodox notion of competition (Possas, 2002; Schumpeter, 1942).

${ }^{12}$ Microsoft/Skype (EU/DG-COMP - 2011), Genzyme/Novazyme (USA/FTC - 2004), AT\&T/T-Mobile (USA/DOJ - 2011) are important examples of cases that were analyzed in other dimensions different from the traditional price one.
} 
As we saw in the previous section, defining the relevant market and evaluating concentration are usually how antitrust authorities start merger analysis. The necessity of changing the procedures and concept of doing so is claimed by some authors. In particular, one solution to do this in a market where innovation is at stake was presented by Gilbert and Sunshine (1995): the innovation market analysis (IMA). The authors suggest using R\&D market share as a concentration measure as firms compete through R\&D spending. Even though this approach was heavily criticized (especially due to the lack of an empirical link of concentration and innovation and the notion that a high share of the innovative effort is made by smaller firms), it inaugurated the debate about the possibility of using an alternative approach of merger analysis in Schumpeterian markets.

One major topic for building an alternative approach for merger analysis in innovation markets is the focus on potential competition. A firm that has the capabilities needed to develop a new product that may compete in a relevant market is a potential competitor: in a market where competition is innovation-based, any successful innovator has a chance to enter the market. If innovation cycles are short, the threat is even more credible. So, in order to fully define the relevant market in a Schumpeterian market, it is necessary to include the firms with the capabilities needed to eventually develop a product and enter the market (even if this product is not under development yet). This view may be referred as the 'capabilities approach'.

By following this approach, any firm with the capabilities to develop a product that will be able to compete in the product market is a potential competitor. Cases such as: (i) the firm has the capabilities to develop a new product but is not developing one yet; and (ii) the firm is already developing an innovative product, but its introduction to the market has not happened yet, are cases in which the firm has no market share in the present time but its competitive significance may be enormous. Startups usually fits these cases.

As an example of the American experience, when Genzyme (a large pharmaceutical company) acquired Novazyme (small pharmaceutical startup), the last one was a small and recent company with no products on the market, but was one the two companies that were developing a treatment to Pompe disease (the other being Genzyme itself). Novazyme's market share was not a good proxy for its competitive significance. The elimination of a firm in one of the two cases listed above may mean a great harm to innovation through two main aspects: i) one less innovative player may lead to the reduction of pressure for innovating is this market (one less potential entrant), ii) the elimination of a research path may lower the chance of new products entering the market (less diversity).

The most recent Horizontal Merger Guidelines (DOJ/FTC, 2010, pp. 18) discusses potential entrants. It is stated that the analyses must be done by using projected market shares:

In analyzing mergers between an incumbent and a recent or potential entrant, to the extent the Agencies use the change in concentration to evaluate competitive effects, they will do so using projected market shares. A merger between an incumbent and a potential entrant can raise significant competitive concerns. The lessening of competition resulting from such a merger is more likely to be substantial, the larger is the market share of the incumbent, the greater is the competitive significance of the potential entrant, and the greater is the competitive threat posed by this potential entrant relative to others.

Even though projected market shares can be a good way to assess entry in traditional price competition markets, it is not accurate to proceed like this in a Schumpeterian market, as we have shown. The capabilities of the firms must be taken into account in order to fully analyze the competition in an innovation-driven market.

The diversity argument, defended by some authors, reinforces the capabilities approach, as if it is assumed that the more firms capable of innovating in a given area, the bigger the chance of having wellsucceeded innovative products, in other words, it is better that are many potential capable competitors. It is important to preserve diversity in the market: if a merger gets together two firms with different innovation paths, one of those paths (maybe even both of them) may be eliminated. 
In that line, Sidak and Teece (1990, pp. 31) affirm that antitrust agencies should make an effort to protect diversity in the market:

Competition policy authorities as well as other agencies must be concerned with protecting economic diversity and meaningful variety in organizational forms. Policymakers need not focus on a particular market; their focus should be broader because some of the best candidates for new entry and radical innovation exist outside the market.

Kerber (2011, p.14) states that there are two different types of diversity reducers:

two different effects should be distinguished: (1) Mergers and R\&D agreements can lead to a reduction of parallel experimentation with new problem solutions, for example, by eliminating parallel research projects (or competing products or services). This might be directly restricting competition from a competition law perspective, because the research projects or products are substitutes aiming at the solution of the same problems. (2) It is a different effect, if the lower number of firms through larger firm size and firm concentration leads generally to fewer sources of innovation and therefore to fewer search activities for new problem solutions.

Returning to the example of the Genzyme/Novazyme (2004) merger in the US, both firms were developing treatments for Pompe disease: three different treatments were being developed by Genzyme and one by Novazyme. A possible threat considered by the FTC was that there would be low incentives to Genzyme quickly bring the treatments to market. Genzyme successfully convinced the agency that Novazyme's treatment would be a second-generation treatment and innovation incentives would be preserved. The merger was approved and the FTC was heavily criticized because of that decision, especially because Genzyme decided to continue the developing of only one of its own treatments, interrupting the other two and Novazyme's treatment. The Genzyme/Novazyme case shows how important it is to maintain diversity: a merger that gets together firms with different innovation paths may be harmful to innovation.

However, as discussed in the beginning of this section, there is not a clear relation between innovation and concentration. In fact, concentration could also lead to more innovation in some markets. So, the question is how to evaluate whether innovation incentives will be maintained or not after a merger. Shapiro (2011, p. 383) offers three guiding principles that may define how incentives will be affected by some merger.

The first principle is the Contestability one, which is the incentive to gain and protect profitable sales by providing greater value to consumers, what enhances innovation incentives. In other words, a sale is contestable if other firms may take away this sale by providing a better product or a more innovative one. For example, Contestability works as incentive for both the potential competitor (has the incentive to enter the market and gain sales) and the incumbent (has the incentive to protect its own sales). The Appropriability principle is the second one and it says, in general, that the greater the fraction the innovative firm can capture of the welfare generated by its own innovation, the larger the incentives to innovate are. The Contestability and Appropriability are basically about the incentives to innovate, while the last principle, the Synergies principle, is about the actual ability to innovate. Synergies are enhancements of innovation capabilities generated by the combination of complementary assets (Shapiro, 2011) ${ }^{13}$.

The three guiding principles are useful to predict post-merger incentives. By checking how these three principles are affected by the merger, one can infer the impact to innovation. If the acquired firm is a maverick, in antitrust language terms (or a disruptive and more aggressive competitor, more generally), eliminating it is even more problematic to innovation. Given the uncertain nature of innovation, checking

\footnotetext{
${ }^{13}$ About synergies, it is important to state that the American Horizontal Merger Guidelines considers the ability of better to conduct R\&D more effectively as a form of efficiency (DOJ; FTC, 2010, pg. 31).
} 
how incentives behave with the merger may be a good way to assess its effects. The most recent American Horizontal Merger Guidelines clearly addresses these principles and considers two different ways that a merger can reduce the incentives to innovate:

That curtailment of innovation could take the form of reduced incentive to continue with an existing product-development effort or reduced incentive to initiate development of new products. The first of these effects is most likely to occur if at least one of the merging firms is engaging in efforts to introduce new products that would capture substantial revenues from the other merging firm. The second, longerrun effect is most likely to occur if at least one of the merging firms has capabilities that are likely to lead it to develop new products in the future that would capture substantial revenues from the other merging firm. The Agencies therefore also consider whether a merger will diminish innovation competition by combining two of a very small number of firms with the strongest capabilities to successfully innovate in a specific direction. (DOJ; FTC, 2010, pg. 23)

Finally, after this brief presentation of the main author concerned with innovation effects in merger control and their criticism and proposals to antitrust policy, we can consider some special issues that arise when a startup firm is involved. First, here the relevant market delimitation and the size of the firm as proxy of market power is still an issue. There is no doubt that independent startups are born as small firms. When a merger involves a firm that is not big enough to reach the minimum criteria for notification, the merger is automatically approved as it does not pass through the authority's scrutiny. It is also true the consideration that there may be a great increase in market power of the acquirer as a result of the acquisition on the startup.

In some cases a startup or a small knowledge-based company may be a relevant competitor, despite its null or reduced market share, due to an innovation that can radically alter the dynamics of the market or may be strategically expensive to replicate. In order to evaluate whether a startup is a relevant competitor or not, antitrust agencies may check first if the innovative product is already in the product market. Or whether their innovative capacity will define their ability to play a major change in the market or not. When it is not already in the product market definition, the agency can check if it is possible or not to evaluate the innovation process, in other words, check the stage of development of the new product and its value in terms of strategy to the acquiring firm. By doing so, the agency can answer if the innovation is likely to succeed. In this case, the startup may also be a relevant competitor regardless of its size. Thus, the capability if innovating will determinate the merger effect to the market, not its size.

Secondly, there are the changes in the incentives after the merger. As O'Connor (2013) says:

Sometimes, new entrants or startups are actually more of a pro-competitive force if they acquired by a major company and integrated into their platform and products (Apple's acquisition of Siri and Google's acquisition of Android being recent examples of this). In fact, acquisition is an extremely common startup exit strategy, and many startups wouldn't have an exit scenario without it. However, there are certainly instances where the acquisition of disruptive technologies can be anticompetitive. When a disruptive competitor threatens to undercut the revenue of an incumbent (or their entire business model), incumbents have an incentive to buy the competitor and bury its technology, so regulators should be suspicious about the acquisition.

The argument present an important issue: buying and selling is intrinsically to independent start up business. Also, O'Connor's points are directly related to Shapiro's debate about Synergies and Contestability: the integration of the startup in the acquirer's platform may be a synergy related to the merger, and the discontinuity of startup's technology path as a result of the acquisition, when it is the case, clearly occurs based on the contestability principle.

In an acquisition of a startup by a large and well stablished firm, if the large firm is likely to lose profitable sales to the start-up, the Contestability principle says that there are incentives to reduce innovation. 
On the other hand, there may be synergies as results of the merger, like getting together the expertise of both firms, the financial robustness of the large firm with the innovation project being developed by the startup (what will increase its chance of success), also other complementary assets in general and the access to the consumer's base of the large firm by the startup. Both cases can happen and the antitrust agencies must check them in order to make decisions.

That being said, it is easy to say that the identity of the buyer matters in cases involving startups. This means that although this sort of transactions are the reason for many startups' existence, the antitrust concern may be about who is going to buy it. In some scenarios, a larger firm with products that compete in the same market being sold or developed may have the incentive to discontinue both its own innovation projects and the startup's ones. If the acquiring firm actually has incentives to diminish innovation, there may be two results from the merger: eliminating a source of innovation (the startup's project or product) or just eliminating an independent competitor and maintaining the development of its project.

In resume, analyzing a merger or acquisition involving a startup is not easy. Prospect decisions concerning price or innovation effects are already challenging even when it involves merging firms with large sizes. Therefore, some of the issues that the antitrust agency has to deal with, as presented above, are: minimum size for notification, the small (or even non-existent) market share, capabilities and incentives postmerger to innovation, and uncertainty about future performance. Dealing with it is a complex process, but it is clear that agencies should take a closer look in some special cases.

\section{Startups or small knowledge-based companies' mergers: selected cases and recent experiences}

In this section, we present and analyze briefly two important cases: the Google/Waze (US approach) and Facebook/WhatsApp (EU approach). We set up the case from the available information and by combining it with the conceptual insights discussed in the previous sections. As stated in the introduction, there are not many cases that fit our discussion. Those that exist are mainly published in specialized blogs or magazines, but they generally do not present a complete analysis and were not part of an antitrust merger review. These two cases are particularly relevant to try to understand how the US and EU antitrust authorities deal with these sort of industries and to dialogue with the conceptual discussion presented before. Later, we present an interesting selection of Brazilian cases, with the intention of open the subject and identify some further questions and challenges for competition policy's theory and practice in that country.

\section{a) Google/Waze}

Google, primarily known for being the largest internet search engine in the Western world, has always been known for the continuous seek for new directions in its growth and its innovation strategy. This growth-by-acquisitions strategy has opened the path for some research in Europe, such as the ones of ICOMP (2011, 2012), discussing Google's growth strategy as focusing in the monopolization of the internet market. According to Popper (2012), from 2001 to 2015, Google has purchased and integrated over 110 companies. In 2014 alone, it bought up 25 companies, one firm every two weeks. If we count the firms acquired for patents and intellectual property between 2001 and 2011, the total number is 79. When founder Larry Page took over as CEO in April, 2011, under his administration, the company abandoned a number of small initiatives and refocused the company around 7 core product divisions. ${ }^{14}$ As Popper (2012) points out:

Google has taken plenty of flack for its extremely broadsome would say lack of focus. But by and large it's been the most successful among the massive tech firms when it comes to incorporating new companies. Doubleclick and AdSense, both acquired, are

\footnotetext{
${ }^{14}$ See Annex 1 to a graphic representation of Google's acquisition path and the 7 core divisions. Taking a look at Google's competitors, it becomes clear how astonishing these numbers are: Facebook acquired ten companies in 2011; Apple, Amazon, and Microsoft only three. These acquisitions are not irrelevant ones, as it is showed in Annex 2, the acquired firms are central players in Google's products/services portfolio.
} 
major drivers of Google's revenue. YouTube dominates online video. Android goes head-to-head with Apple in mobile. And it's not just companies that are bolted on whole cloth. Premier products like Google Maps, Docs, Analytics, and Voice were also crafted in large part by teams brought in from outside

In 2013, Google bought Waze, a four-year-old Israeli firm that developed a free application currently available on the iPhone and Google Android devices, which incorporates real-time GPS data from its nearly 50 million users to deliver highly accurate and useful traffic and navigation information. Waze users can edit maps with details like gas prices, speed traps, road construction and traffic accidents. According to its CEO, Noam Bardin, Waze is "an innovative mobile mapping platform that crowd-sources user data to help drivers avoid traffic congestion, road construction and police speed traps" and she adds: "We feel that we're the only reasonable competition to [Google] in this market of creating maps that are really geared for mobile, for realtime, for consumers, for the new world that we're moving into." (Time, 2013). Waze was founded in 2007, and at the moment of the takeover it had about 100 employees, mostly based in Israel, with offices in the Silicon Valley and New York. According to CrunchBase, the company raised US\$67 million in venturecapital funding. Microsoft was an early investor, but apparently did not make a bid for the company.

From Google's side, the purchase could be seen as part of a growth strategy through acquisitions ${ }^{15}$, either to eliminate or incorporate competitors or/and in order to acquire skills to build a broader scope of products and services (Popper, 2012; O'Connor, 2013). Google Maps had been launched by Google in 2005 as a desktop web mapping service and in September 2008 Google released it for mobile devices. Only to give an approximate idea, according to StatCounter, in 2004, Google concentrated $84 \%$ of mobile search market share. So, according to TIME (2013), the deal was seen by FTC officers as a defensive play to remove a competitor to Google Maps and keep the service out the hands of rival tech giants Apple and Facebook, which had also been interested in buying the company.

Google's Waze acquisition deal was closed in one billion dollars. Given that Waze turnover was less than 70.9 million dollars, the deal was not formally investigated, even though the FTC did some preliminary inquiry about the case. Nonetheless, the specialized media, some antitrust analysts and also the FTC officers began to study and monitor the case, because of its implications in innovative terms. According to O'Connor (2013), the fact that Waze turnover was less than 70.9 million at the moment of the deal was no doubt a limit to the intervention of the FTC which should intervene ex officio: "This doesn't mean that the antitrust agencies can't challenge it. However, it does mean that challenging the acquisition would be messier (and therefore less likely), because the Department of Justice would have to unwind the deal (as opposed to what usually occurs, where antitrust agencies block the consummation of a deal)." The O'Connor observation shows us how important are the delimitation of a threshold to the transaction value, which is the actual complementary procedure in the US.

Under the traditional approach, the relevant market definition is the first central issue to the analysis. This issue has to do with whether the relevant market is the market of apps for smartphones, dominated by Google and Apple, or if it is a broader market of turn-by-turn navigation market, which would include dashmounted and other types of automobile GPS units, such as those made by other firms such as TomTom and Magellan. Certainly, the later configuration would reflect into least anticompetitive concerns, as this includes players in the market such as Telenav and TCS, offered by AT\&T and Verizon platforms, respectively. Concerning the modification of market structures involved, in particular barriers to entry, disruptive competition often undercuts the business model of big incumbents by providing a similar good and service at much cheaper prices. If barriers to entry for that market are high, then the incumbent could acquire the dynamic startup for the purpose of killing it or slowing down the disruptive innovation and protecting its legacy revenue stream. However, for the case of Waze, O'Connor (2013) says:

${ }^{15}$ The timeline of Google's acquisitions is shown in Annex 1. 
Since a dynamic open source mapping project exists, OpenStreetMaps (in fact, Foursquare used OpenStreetMaps to replace Google Maps), it is not that much of a stretch to think that other social networks or major tech companies could build their own Waze competitor if they were so inclined. Barriers to entry, particularly for companies that already have a large user base, appear low.

Again in line with the Principles and theoretical reviewed, regarding the assessment of anticompetitive effects and competitive conditions, O'Connor (2013) points out that the questions to answer are:

Is Waze's social mapping business model one that might undercut Google's revenue stream...? Or is it likely that Google will integrate the best of its own mapping features (and advertising business models) with Waze to create a better, more competitive product? If regulators believe the answer to be the former, they would probably attempt to unwind the merger. If regulators think the latter is more likely, they would have no problem with the merger.

The existence of Google Maps makes the operation a horizontal merger. From the diversity point of view, it eliminates one source of innovation and the diversity of innovation paths. In Shapiro words, it is important to analyze Google's incentives to innovate when acquiring Waze and how those incentives changed after the merger. The latter was contesting a market that belonged to Google through Google Maps, so Google could have the perspective of losing market share. Applying the Contestability principle, this perspective may have influenced Google, as Waze could be a threat itself or be acquired by a relevant player outside the market. On the other hand, pro-competitive claims related to possible synergies could be valid if Waze benefited from Google's platforms, knowhow and clients.

\section{b) Facebook/WhatsApp}

Another important merger case was the acquisition of WhatsApp by Facebook in 2014. Facebook agreed to spend US\$ 19 billion ${ }^{16}$ to acquire the company that offers instant messaging service to 600 million users worldwide $^{17}$. The FTC gave the green light to the proposed acquisition without investigating it longer than the usual first 30-day period to decide whether the Commission will ask for further information or close investigations. On the other hand, the European Commission (DG-Comp) took longer to decide whether the deal should be approved or not, but ended up allowing it to go on. When it comes to notification, transaction value was more than enough to match the minimum requirements of the size of transaction test ${ }^{18}$ in the American system and the turnover thresholds of the European system ${ }^{19}$.

DG-Comp divided it into three relevant markets: consumer communication services (the product market was defined as communication apps for smartphones), social networking services and online advertising. One critical issue raised was the dynamic environment of competition, especially the presence of short innovation cycles, great number of players and great condition of entry (DG-COMP, 2014). Those aspects make market share a bad proxy for market power (as discussed on section 3): the structure of the market can change within months. An example is Telegram, a competitor that reached 35 million users in March 2014, six months after launch. A similar view was used by DG-Comp in the previous year: the assessment of Microsoft's acquisition of Skype $(2011)^{20}$ showed as one of major arguments the influence of the short innovation cycle to show the great and constant contestability of the market (DG-COMP, 2013).

\footnotetext{
${ }^{16}$ As stated in the European Commission assessment, the payment was divided in Facebook shares (US\$ 12 billion), cash (US\$4 billion) and restricted stock units after the closing of the transaction (US\$ 3 billion).

${ }^{17}$ According to the European Commission, WhatsApp had 600 million users around the globe by June 2014.

${ }^{18}$ If the transaction exceeds a previously defined threshold, the transaction must be notified independently of the result of the size of person test. In 2014, the minimum was \$303.4 million. In 2017 the threshold is 323 million. https://www.ftc.gov/system/files/documents/federal_register_notices/2017/01/clayton_7a_publishe_1-26-17.pdf

19 The European requirements were presented in section 2See more in: http://ec.europa.eu/competition/mergers/procedures en.html ${ }^{20}$ http://ec.europa.eu/competition/mergers/cases/decisions/m6281_924_2.pdf
} 
By considering the agency's view under the principles stated before, one of the most important drivers of innovation is diversity. The coexistence of different paths is one of the forces that could make the introduction of innovation more likely to occur. At first, eliminating an innovative player such as WhatsApp could be seen as a possible source of reducing innovation. However, the agency considered three aspects. First, consumers expect that communication apps for smartphone will be free; thus the player that decides to impose a fee may lose shares rather quickly (especially if considered how easy it is for a consumer to change to another competing service). The doubt to this argument would be for network effects and lock-in. As there is no price competition, firms compete through innovation essentially and consumer base network. Second, there are many players in the first two relevant markets considered by DG-Comp (communication apps for smartphones and social networking services), so it is unlikely that innovation would be diminished: competitive pressure will continue strong post-merger and diversity should be maintained. Third, as we have discussed before, if a successful innovator is able to capture sales after releasing its product, the market is contestable and the other firm may have incentives to acquire the innovator in order to prevent losing sales, as the Contestability Principle says. However, DG-Comp did not consider Facebook and Whatsapp as close competitors, but as complementary (the user base overlaps significantly, meaning that many consumers used both services), what mitigates the possibility of an acquisition to reduce or eliminate innovation. Finally, the final decision undertaken by DG-Comp appears not to conclude about other potential anticompetitive effects not related to post merger innovation, such as consumer information policies, and other ways of diminishing consumer welfare.

\section{c) Brazilian selected cases}

Knowledge-based takeovers are not only restricted to the developed countries. Increasingly, developing countries are being part of this global trend. In fact, several startup acquisitions took place in Brazil in the last years. In this section, we give a snapshot on some of these cases, in order to introduce the knowledge-based startup takeovers discussion in the Brazilian context. We do not present an exhaustive list of cases and we were not able to collect significant case information because there is no systematic data available or significant case law in the Brazilian Authority concerning our subject. Nevertheless, this is one of our further research goals that we intend to pursue.

To better contextualize the Brazilian cases, we shall briefly present the Brazilian antitrust institutional framework. The competition authority in Brazil, CADE (Conselho Administrativo de Defesa Econômica), is responsible for analyzing mergers and anticompetitive practices. Merger control is one of the main roles played by CADE, as defined in federal law 12.529/2011. Mergers investigated by CADE may be through the simple procedure, which may take only few weeks to get approved, or the complex procedure, taking up to 1 year for the final decision. The simple procedure applies only to cases that show no overlap between the firms, less than $20 \%$ joint market share (30\% in cases of vertical mergers), low increase in concentration and joint ventures made to act in non-related markets. The complex procedures may result in approval, block, or subject to remedies imposition by the General Superintendence. The last two cases are sent to the Tribunal, which has the final call.

The minimum requirements for submission of mergers in Brazil are: i) one the parties must have annual revenue of at least $\mathrm{R} \$ 750$ million, and ii) at least one of the other parties must have annual revenue of at least $\mathrm{R} \$ 75$ million $^{21}$. As in many cases startups usually make less than $\mathrm{R} \$ 75$ million, most of the acquisitions are not submitted for further analysis. Table 1 shows some of those acquisitions, none of which were submitted to CADE (the Brazilian national antitrust authority):

\footnotetext{
${ }^{21}$ Using the exchange rate of June $11^{\text {th }}, 2017, \mathrm{R} \$ 750$ million and $\mathrm{R} \$ 75$ million corresponds to around US\$227.5 million and US\$ 22,7 million respectively.
} 
Table 1 - Startups and small knowledge-based acquisitions in Brazil - Selected cases

\begin{tabular}{|c|c|c|c|}
\hline Year & Acquiring Firm & Acquired Startup & Sector \\
\hline 2015 & Kroton & Studiare & Education \\
\hline 2015 & B2W & InfoPrice & E-commerce \\
\hline 2016 & Glassdoor (USA) & Love Mondays & Employer Review \\
\hline 2016 & Tivit & One Cloud & Business Process Management \\
\hline 2017 & Docway & Dr. Vem & Health Apps \\
\hline 2017 & Somos Educação & AppProva & Education \\
\hline
\end{tabular}

Source: own elaboration based on secondary sources.

The first and the last cases, involved a large education company (Kroton, owner of many private universities and Somos Educação, owner of many services regarding education, including some private schools) buying startups: Studiare (developer of an adaptive learning system) and AppProva (developer of a platform where students can test their knowledge), respectively. Although it is not possible to make definitive conclusion due to lack of information, it is possible to say that both cases were not characterized by an actual threat to the large companies, since the startups were offering a complementary product not a competing one. ${ }^{22}$

B2W Digital is a company founded in 2006 as the result of a merger involving Americanas.com and Submarino, two large e-commerce Brazilian companies originally founded in 1999. Besides the e-commerce business itself, B2W also owns companies that provide services related to it, such as delivery, IT and financial services (mostly used by the company itself). B2W's business strategy included acquiring some companies along the way: in 2013, B2W acquired four companies, three of them were technology-based (the other one is a delivery company). More recently, in 2015, B2W bought a company called Sieve Group (pricing), which had already bought two months earlier a startup called InfoPrice, a knowledge-based startup focused on Business Intelligence and pricing (founded by students of the University of São Paulo in 2013). That said, the acquisition strategy is focused on buying companies vertically related to the e-commerce business itself, and considering that $\mathrm{B} 2 \mathrm{~W}$ is one of the largest company in this market, this sort of strategy deserves a closer look of antitrust authority in order to evaluate the potential risk of foreclosure (technological or market). ${ }^{23}$

Glassdoor is an American website created in 2007 where employees anonymously review the companies they work in. In 2016, Glassdoor bought Love Mondays, a Brazilian startup created in 2013 with a similar goal. Even though both companies offered the same product, the geographical market definition is somewhere between local and national (considering that workers may use the information provided in the website to get a job in other city within the country). Glassdoor bought Love Mondays to enter the Latin American market, so there was no competitive harm. ${ }^{24}$

Tivit is a Brazilian Information Technology Management and Business Technology Management company created in 2005. In 2016, they bought the Brazilian startup called One Cloud, founded two years earlier. One Cloud offered services designed to support cloud computing which was not a horizontal threat to Tivit.

\footnotetext{
${ }^{22}$ Informações obtidas em fontes secundárias e disponíveis em: http://link.estadao.com.br/blogs/start/norte-americana-intuitadquire-startup-brasileira-zeropaper/ https://techcrunch.com/2015/01/21/intuit-buys-zero-paper-its-first-acquisition-in-brazil/

23 Informações obtidas em fontes secundárias e disponíveis em: http://www.lasa.com.br; http://www.valor.com.br/empresas/4106394/b2w-compra-empresa-de-tecnologia-dos-controladores-daamericanas; http://oglobo.globo.com/economia/b2w-compra-empresa-de-tecnologia-dos-controladores-da-americanas-16536964 http://www.baguete.com.br/noticias/26/06/2015/b2w-compra-sieve-por-r-886-milhoes;

${ }^{24}$ Informações obtidas em fontes secundárias e disponíveis em: https://conteudo.startse.com.br/mercado/felipe/glassdoor-adquirestartup-brasileira-love-mondays-e-quer-investir-pesado-por-aqui/;
} 
Docway is a startup created in 2015 and acquired by the large group Garantia the following year. Docway was considered the "Health Uber": an app to connect doctors and patients, especially to provide home medical care. In February 2017, Docway bought another startup named Dr. Vem, which provided a competing service. This transaction maybe seen as one example of elimination of diversity while they were both making innovation efforts in the same relevant market, so diversity was reduced post-merger. ${ }^{25}$

As said, this Brazilian analysis still has to be extended, given the novelty of most of the cases. Also, it is hard to draw any definitive conclusion as there are no open data about the merging firms or about the cases. By looking at these selected Brazilian cases, most of them were made by companies that had a complementary products or services, not a competing one. In general terms, those cases have a tendency to preserve innovation, especially if taken into account the Contestability Principle: they were not threats to the large companies' revenue. Besides, in many cases they may even have Synergies that justify the operation. However, the preservation of the diversity is still an open question. Equally important is the merger threshold limits. Brazilian authority is far from having a big picture of startup or small tech-firms acquisitions, even when we think about large companies acquisitions.

\section{Conclusion}

This paper was devoted to answer two main questions. First, how the antitrust authorities should consider knowledge-based startups or small firm's acquisitions and what are the current institutional challenges. We have looked at the antitrust theoretical debate and examined the recent experience abroad in order to extract some insights about these questions, since this specific debate was not undertaken in Latin American innovation and in antitrust research in general. Also, we briefly explored some selected Brazilian recent cases to draw some policy and academic agenda concerning the knowledge-based startups or small companies' merger control in that country.

Concerning to the first question, as showed in section 2, the antitrust arena is not a static field. It has been co-evolving both conceptually and with respect to its enforcement with the different historical and competition challenges faced by the American economy. More recently, the emergence of a new technoeconomic paradigm mainly based in the ICT technologies naturally have influenced the ongoing antitrust debate and changes. Although it could be expected some more conclusive answers, there is still no definitive consensus about how to evaluate this sort of mergers, mainly in knowledge-based sectors, where the Schumpeterian competition takes place. The US merger review considers merger effects on innovation in the 2010 Horizontal Merger Guidelines, but it is still not very specific about the procedural to deal with this matter.

In this context, we could identify some contribution in the antitrust debate. We stated that the conventional antitrust merger analyses, centered in static and price competition, is insufficient. We also stressed that assessing potential competition and innovation capabilities is crucial, despite market concentration, as startup or small knowledge-based companies' competitive significance is not well reflected by its actual or relative revenue. In that sense, startups are in the arguments' frontier since, not only for the innovative dimension of competition in their markets, but because they have, by definition, a very insignificant or null market share. Also in some markets we can see a high volatility of market shares.

Related to this, we highlighted, in line with Kerber (2010) and Sidak and Teece (2009) that to preserve capabilities and diversity is crucial in those sectors in which knowledge and intangible assets are of major importance to allow entry. As mergers in many cases reduces the diversity, in this evaluation, the Appropriability, Contestability and Synergies principles proposed by Shapiro (2011) are the main conceptual tools to evaluate post-merger incentives to innovate in the literature. In particular, the knowledge-based

25 Informações obtidas em fontes secundárias e disponíveis em: http://www1.folha.uol.com.br/mercado/2016/08/1806341inspirados-no-uber-aplicativos-resgatam-as-visitas-de-medico.shtml 
startups acquisitions, at least with the relevance and speed that occurred in our days, are a quiet new matter and consequence of the ICT techno-economic paradigm. Thus, concerning this kind of mergers, we raised some issues to be addressed: the minimum size for notification, the small or even non-existent market share and the importance of identifying the buyer and their changes in incentives to maintain the innovation path are some specificity that turns the analyses even more complex.

The case selection fits well the concerns raised in the previous section. Again, we certainly could not draw conclusive analyses, as we do not have enough information about the cases. In the case of Google/Waze case, it is clear that Google has a strong strategy of buying startups, and that they may be potential or real competitors. The merger deserves a deep look because it may have effects (positive or negative) in the firm's incentives to innovate, considering especially the Contestability and Synergies principles. The merger is also very illustrative to the view that the size limits of the firms and the submission threshold may not be adequate to these markets, as they lead to the non-submission and may be ignored by the antitrust authorities. The US has a mechanism to make some of the transactions involving startups get notified: if the transaction is valued in more than US\$323 million, the parties must notify the FTC or the DoJ (what does not necessarily mean that it will get investigated, as in this case). Europe, Brazil and many countries check only size of the parties, what should be changed in order to give the opportunity for these mergers to get looked at. This last fact, certainly, lights up a red light to a real problem as Waze is not so irrelevant and this is probably a suitable example of how our current antitrust definition to "small", or irrelevant in assessing increase of market power, is not compatible to IT relevant markets. The high value of that operation is also a sign that there are some inconsistences with these two criteria in this sort of markets.

Facebook/WhatsApp case presents us an example where the great number of players and short innovation cycles makes the acquisition less likely to be anticompetitive, under the scrutiny of antitrust authorities: diversity was presumed to be maintained. The fact that WhatsApp and the competitors offer the service for free makes innovation more likely to keep coming up. In the authority view, short and dynamic innovation cycle and non-price competition were the main argument to diminish the role of market shares in defining market power, making this case important to our discussion even though it may not be considered a small company acquisition. In other words, leaving behind other potential anticompetitive issues about data and personal information's control, the volatility of market share and the intense dynamic of the market reinforced the idea of the continuing path of innovation and absence of any consumer reduction of welfare in the agency's point of view.

We can suggest some implications to the antitrust field and to Brazil, in particular. First, it seems urgent to introduce much more conceptual insights about innovation in antitrust analysis, given that most dynamic markets involve some type of Schumpeterian competition. Second, assuming the specificities and the practical and conceptual difficulties of the analysis, much more research is needed, particularly with respect to methodological tools and more qualification of the existing principles about the postmerger capabilities and incentives to innovate. Third, it may be relevant to consider the likelihood of anticompetitive effects of mergers, despite the low size of the acquired firms if they have succeeded in innovation strategies, especially when they directly compete with the acquiring firm. This may be not a minor point in these industries where startups or small technological companies are a major source of innovation success. The introduction of additional or even informal thresholds for the value of transaction may be a starting point. Thus, as the competition law does not include any submission threshold criteria regarding the value or assets negotiated in the transaction, but only the revenues of the merging entities, the selected cases draw the conclusion that there may be important cases that are not passing under the scrutiny of the Brazilian agency, such as the merging strategy of B2W.

Additionally, regarding Brazil and other developing countries, introduced in the analysis, a fruitful conceptual area of research in order to deepen the dialogue between innovation and competition policies. In this context, some insights may be pointed out. Structural productive heterogeneity is a reality of developing countries, particularly - but not only - Latin American ones (Pinto, 1970; Rodriguez, 2006). As said in the 
introduction, the MERCOSUR 'catching up' efforts, trough policies that aim to stimulate the emergence and consolidation of a cohort of knowledge-based firms, mainly in biotech, IT and audiovisual industries should be contemplated and articulated by the innovation and competition policy authorities of these countries. It would be a contradiction - and a waste in the public recourses - if the innovative efforts oriented to diversify and modernize the productive structure are locked in by an anticompetitive takeover with a considerable reduction of innovation. In this sense, although there is not a definitive and single merger 'evaluation', as each case (under certain threshold of analysis) deserves attention to its singularities and derived conclusions, we consider that the preservation of industry incentives to innovate and the avoidance of 'locking in' in the local technological trajectories should be an important goal for merger analysis in the MERCOSUR.

Given that the antitrust debate is still open and that, as we could see from the antitrust debate, it is not a static field (it is actually contextualized in each country competitive challenges) an alternative is to complement the antitrust gaps with innovation policy initiatives. In other words, different instrument of the industrial and innovation policy can be used to reduce the risk of losing innovative efforts from mergers. As recently re-introduced by Mazzucato (2013), there are different institutional initiatives to balance the innovation efforts and returns between public and private, but this is over this paper's scope. To conclude, we believe that we were able to present an unexplored issue in a systematic and fist attempt in this way, both from a conceptual and from an antitrust policy oriented effort. 
Annex 1: Google's acquisitions between 2001 and 2013 according to Popper (2012).

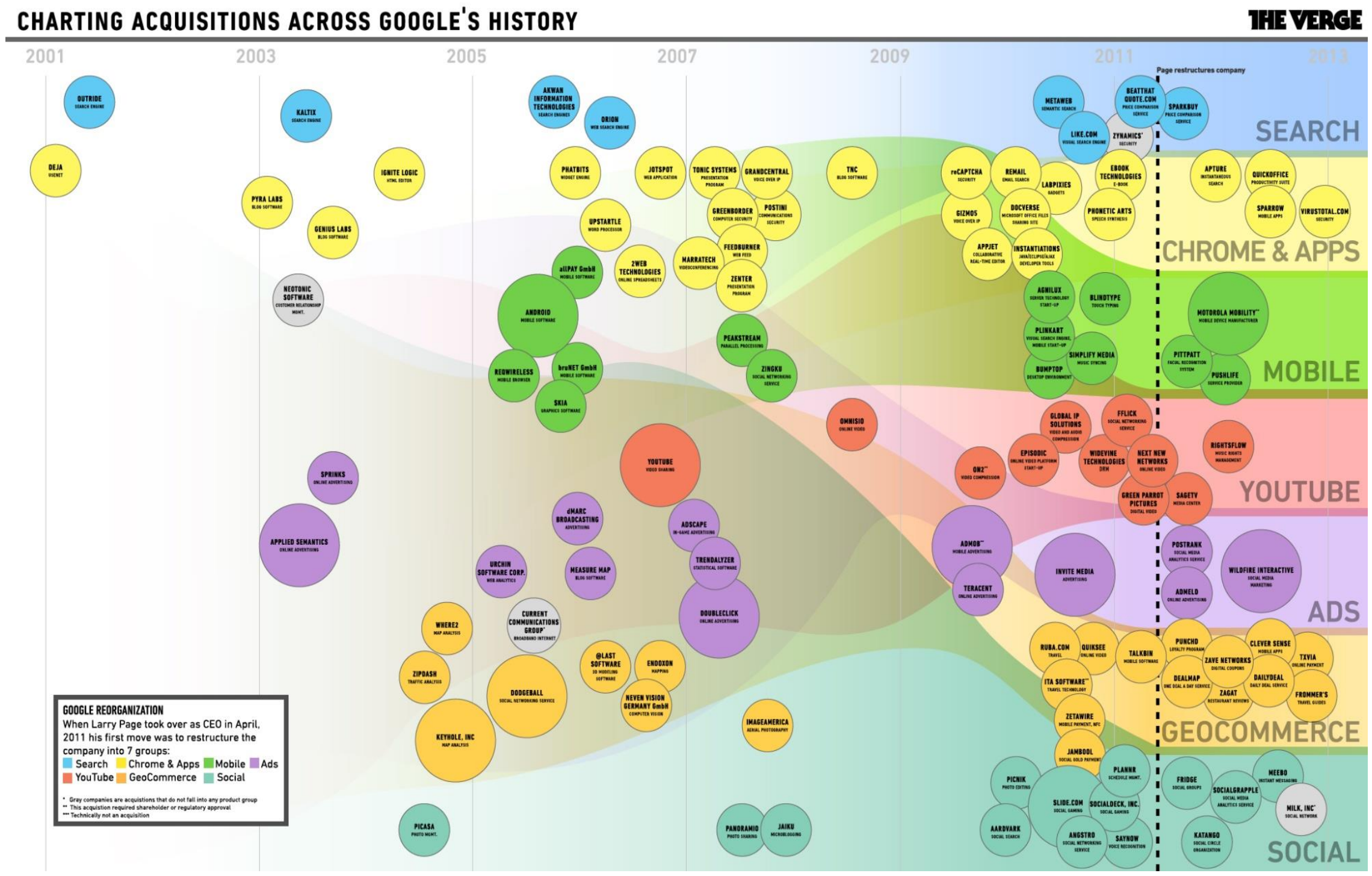


Annex 2: Main Google’s acquisitions between 2003 and 2014 (Statista, 2014)

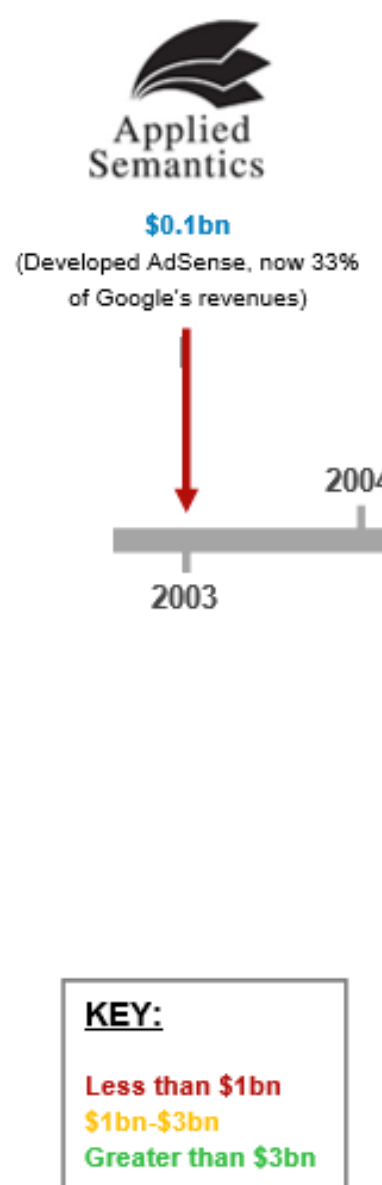

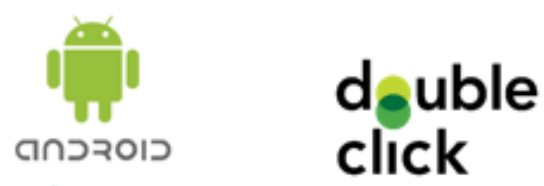

כ0.05n

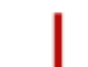

\section{click}

$\$ 3.1 \mathrm{bn}$

(Display advertising)

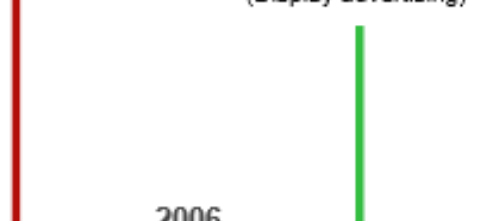

(4)

MOTOROLA MOBILITY

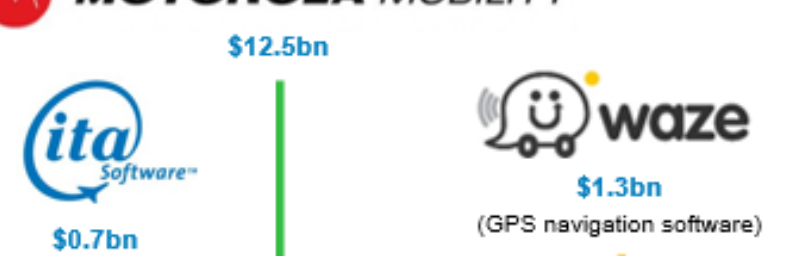

(Travel reservations software)
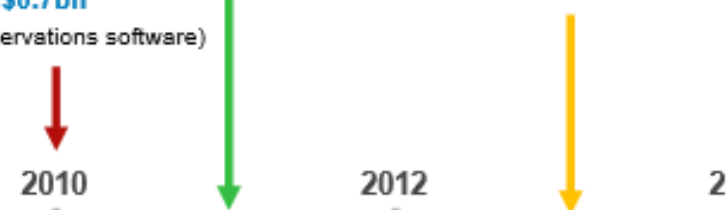

2008

2005

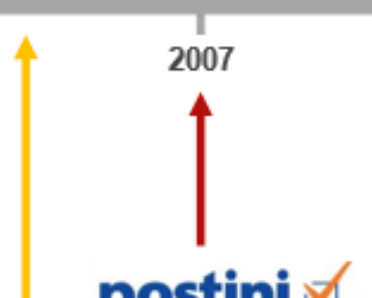

$\$ 0.6 \mathrm{bn}$

(Email security tool, now integrated with Google Apps)

Youtube

$\$ 1.65$ bn admob

$\$ 0.8 \mathrm{bn}$

(Mobile display advertising

network)

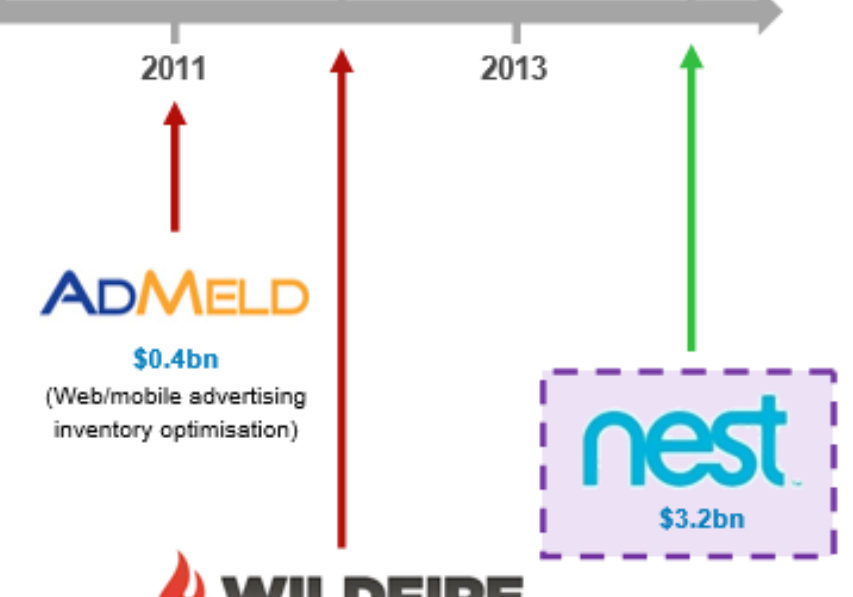

3) WILDFIRE

$\$ 0.5 b n$

(Social media marketing) 


\section{References}

Audretsch, D. (2013) Entrepreneurship and competition policy. In Neumann, N. and Weigand, J. (eds). The International Handbook of Competition. Edward Elgar, 2013.

Audretsch, D. and Keilbach, M. (2007) The Theory of Knowledge Spillover Entrepreneurship. Journal of Management Studies 44(7), 1242-1254.

Audretsch, D. and Thurik, A. (1997) Sources of growth: the entrepreneurial versus the managed economy. Tinbergen Institute discussion paper TI 97-109/3, Erasmus University Rotterdam

Audretsch, D. and Thurik, R. (2000) What's new about the new economy? Sources of growth in the managed and entrepreneurial economy. ERIM Report Series Research Management.

Audretsch, D. Leeuwen van G. Menkveld B. and Thurik, R. (2001) Market dynamic in the Netherlands: Competition policy and the role of small firms. International Journal of Industrial Organization 19 795-821

Audretsch, D., Thurik, R., Verheul, I. and Wennekers, S. (2002) Entrepreneurship: Determinants and Policy in a European-US Comparison. London: Kluwer.

Autio, E. (1997) New, technology-based firms in innovation networks symplectic and generative impacts. Research Policy, 26(3): 263-281.

Budzinski, O. (2007) Monoculture versus diversity in competition economics. Cambridge Journal of Economics, 32(2), 295-324.

Cassiolato, J, and Lastres, H. (2008) Discussing innovation and development: Converging points between the Latin American school and the Innovation Systems perspective? Working Paper No. 2008-02, Globelics.

Ceria, S. and Pallotti, C. (2010) Argentina's Offshore Software Industry - Opportunities and Challenges.

Congreso Mundial de Ingeniería de Software, Saint Petersburg (Russia), Available at http://www.lupacorp.com/seafood/Ceria-Pallotti-PaperSeafood1.1.pdf

Danson, M. (1996): New firm formation and regional economic development: an introduction and review of Scottish experience. In Danson, M (ed) Small Firm Formation and Regional Economic Development. Routledge

Department of Justice of United States of America; Federal Trade Commission (2010). Horizontal Merger Guidelines.

DG COMP. (2011) REGULATION (EC) No 139/2004. MERGER PROCEDURE. Case No COMP/M.6281 MICROSOFT/ SKYPE. $2011 . \quad$ Available at: http://ec.europa.eu/competition/mergers/cases/decisions/m6281_924_2.pdf

DG COMP. (2014) REGULATION (EC) No 139/2004. MERGER PROCEDURE. Case No COMP/M.7217 FACEBOOK/ WHATSAPP. $2014 . \quad$ Available at: http://ec.europa.eu/competition/mergers/cases/decisions/m7217_20141003_20310_3962132_EN.pdf

Dosi, G. (1982) Technological paradigms and technological trajectories: as suggested interpretation of the determinants and directions of technical change. Research Policy, 11(3), 147-162.

Dosi, G. (1984) Mudança Técnica e Transformação Industrial. A Teoria e uma Aplicação à indústria dos semicondutores. Classics da Inovação, Editora Unicamp.

European Commission (2004) Benchmarking Enterprise Policy: Results from the 2004 Scoreboard. Commission Staff Working Paper SEC (2004).

Fajnzylber, F. (1983) La industrialización trunca de América Latina. México, D.F.: Editorial Nueva.

Farrel, J. (2006) Complexity, diversity, and antitrust. Antitrust Bulletin, 51(1): 165-173. 
Ferrer, A. (1963) La economía argentina desde sus orígenes hasta principios del siglo XXI. Fondo de cultura Económica. 2004.

Fontes, M. and Coombs, R. (2001) Contribution of new technology-based firms to the strengthening of technological capabilities in intermediate economies. Research Policy, 30(1): 79-97.

Gilbert, B. Audretsch, D. and McDougall, P. (2004) The emergence of entrepreneurship policy. Small Business Economics 22(3): 313-323.

Gilbert, R. and Sunshine, S. (1995). Incorporating dynamic efficiency concerns in merger analysis: the use of innovation markets. Antitrust Law Journal, 63(2): 569-601.

Gonzalo, M. (2015) Desarrollo y extranjerización temprana de capacidades empresariales locales en Argentina: el caso Core Security. Pymes, Innovación y Desarrollo, 2(3): 121-144.

Gonzalo, M., Federico, J., Drucaroff, S. and Kantis, H. (2013) Post-Investment Trajectories of Latin American Young Technology-Based Firms: An Exploratory Study. Venture Capital: An international Journal of Entrepreneurial Finance, 15(2): 115-133.

Gonzalo, M., Federico, J., Drucaroff, S., and Kantis, H. (2011) The "foreignization" of technology-based start-ups and their contributions to local industry. Reflections based on three case studies". 9th GLOBELICS International Conference, Buenos Aires, 2011.

ICOMP (2011) Google under the Antitrust Microscope. Initiative for a competitive online marketplace. October 20th, 2011

ICOMP (2012) How Google Monopolised Online Mapping \& Listings Services. Initiative for a competitive online marketplace. November 15th, 2012

Jorde, T. and Teece, D. (1990) Innovation, dynamic competition, and antitrust policy. Regulation 13(3): 3544.

Kantis, H., Federico, J., Lopez, A., Ramos, D., Castillo, M., Bacic, M., Choupay, E. (2013) “Emprendimientos dinámicos en el cono sur de América Latina?: la clave es el (eco)sistema". Red. MERCOSUR.

Kantis, H., V. Moori-Koenig, and P. Angelelli. (2004). Developing Entrepreneurship. Experience in Latin America and Worldwide. Washington, DC: Interamerican Development Bank.

Kerber, W. (2010) Competition, innovation and maintaining diversity through competition law. In: Drexl, J. Kerber, W and Podszun, R. (eds.) Economic approaches to competition law: Foundations and Limitations, Edward Elgar.

Lundström, A. and Stevenson, L. (2005) Entrepreneurship Policy: Theory and Practice. Nueva York: Springer.

Mandel, M. and Carew, D. (2011) Innovation by acquisition: New dynamics of high-tech competition. Progressive Policy Institute, Policy Memo, November 2011.

Mason, C. and R. Harrison (2006) After the Exit: Acquisitions, Entrepreneurial Recycling and Regional Economic Development. Regional Studies 40(1): 55-73.

Mazzucato, M. (2013). The Entrepreneurial State. Anthem Press.

Motta, M. (2004) Competition Policy. Theory and Practice. Cambridge. University Press. 2004.

O’Connor, D. (2013) An Antitrust Analysis of Google's Waze Acquisition: Disruptive Competition and Antitrust Merger Review. Disruptiva Competition Project.

Perez, C. (2001): Cambio tecnológico y oportunidades de desarrollo como blanco móvil. Revista de la CEPAL, 75. 
Pérez, C. (2002): Technological Revolutions and Finance Capital: The Dynamics of Bubbles and Golden Ages, Cheltenham: Edward Elgar.

Pérez, C. and Soete, L. (1988) Catching up in technology: Entry barriers and windows of opportunity. In: Dosi, G., Freeman, C., Nelson, R., Silverberg, G., Soete, L. (eds.), Technical Change and Economic Theory. London: Pinter Publishers.

Pinto, A, (1970) Naturaleza e implicancias de la 'heterogeneidad estructural' en América Latina. El Trimestre Económico, México, Fondo de Cultura Económica, 37(145).

Popper, B. (2012) Failure is a feature: how Google stays sharp gobbling up startups. The Verge, September 17 th, 2012.

Possas, M. (2002) Concorrência Schumpeteriana. In Kupffer, D., Hasenclever, L. (eds.). Economia Industrial: Fundamentos Teóricos e Práticas no Brasil. Rio de Janeiro: Campus.

Possas, M., Fagundes, J. and Pondé, J. (1996). Política antitruste: Um enfoque schumpeteriano. Estudos Econômicos da Construção 1(1): 1-24.

Rodríguez, O. (2006) O estruturalismo latino-americano. CEPAL.

Schumpeter, J. (1942) Capitalism, Socialism and Democracy. New York: George Allen and Unwin (5th ed. 1976).

Shapiro, C. (2011) Competition and Innovation: Did Arrow Hit the Bull's Eye? The rate and direction of inventive activity revisited. University of Chicago Press, 2011.

Sidak, J. and Teece, D. (2009) Dynamic competition in antitrust law. Journal of Competition Law and Economics 5.4 (2009): 581-631.

Soares, C., Hausmann Tavares, J., Gonzalo, M., Tomassini, C. and Cassiolato, J. (2015) The need of an alternative approach to GVC'S literature. Transnational corporations and national systems of innovation systems in a Latin American perspective. 13th Globelics International Conference, Havana, Cuba

Sunkel, O. (1971) Capitalismo transnacional y desintegración nacional. Estudios Internacionales, 4(16): 361 .

Szapiro, M., Vargas, M., Brito, M. and Cassiolato, J. (2015) Global Value Chains and National Systems of Innovation: policy implications for developing countries. 13th Globelics International Conference, Havana, Cuba

Tavares, M. C. (1985) Acumulação de capital e industrialização no Brasil. Campinas: UNICAMP Editora.

TIME (2013) Crosstown Traffic: Why Google’s \$1B Waze Deal Faces U.S. Antitrust Scrutiny. June 23th, 2013.

Uriona Maldonado, M., Morero, H. y Borrastero, C. (2013) Catching up en Servicios Intensivos en conocimiento: el caso de la producción de software y servicios informáticos de Argentina y Brasil. Revista Iberoamericana de Ciencia, Tecnología y Sociedad, Vol. 8, No. 24

Wasserman, N. (2003) Founder-CEO succession and the paradox of entrepreneurial success. Organization Science 14(2): 149-172.

Zavatta, R. (2008) Financing Technology Entrepreneurs and SMEs in Developing Countries. Washington, DC: infoDev / World Bank.

CrunchBase - www.crunchbase.com

StatCounter - www.statcounter.com

Statista - www.statista.com 